\title{
SISTEM INFORMASI PENGELOLAAN DATA PEMBINAAN KEGIATAN KERJA NARAPIDANA BERBASIS WEBSITE PADA LEMBAGA PEMASYARAKATAN KELAS IIA PEMUDA TANGERANG
}

\author{
Giandari Maulani ${ }^{1}$ \\ Kartika Chandra Buana Sejati ${ }^{2}$ \\ Siti Pujianingsih ${ }^{3}$ \\ ${ }^{1}$ Dosen STMIK Raharja, ${ }^{2,3}$ Mahasiswa STMIK Raharja \\ 1,2,3 J1.Jendral Sudirman No.40,modern,Tangerang,021-5529692 \\ email: giandari@raharja.info,chandrabuana@raharja.info,pujianingsih@raharja.info
}

\begin{abstract}
ABSTRAK
Sistem merupakan suatu komponen-komponen yang saling berhubungan untuk mencapai suatu tujuan, kebutuhan akan sebuah sistem yang terkomputerisasi menjadi landasan dirancangnya sistem informasi ini. Tujuan dari perancangan sistem pengelolaan data pembinaan kegiatan kerja narapidana pada lembaga pemasyarakatan kelas IIA pemuda Tangerang adalah mempercepat cara kerja sipir dalam pengelolaan data mengenai kegiatan kerja dan juga aktifitas yang dilakukan oleh para narapidana, meningkatkan kinerja sipir dalam mengelola data narapidana dan dalam penyajian laporan dengan memanfaatkan sistem komputerisasi sehingga akan mendapatkan hasil informasi yang lebih baik. Dilakukannya perancangan sistem ini karena pada sistem yang berjalan sebelumnya menggunakan proses pencatatan masih manual karena dalam pekerjaannya masih menggunakan penulisan pada kertas, sehingga belum mempunyai sistem yang menghasilkan informasi secara cepat untuk pengelolaan data narapidana yang akan melaksanakan kegiatan kerja. Oleh karena itu kegiatan yang terkomputerisasi ini diharapkan dapat memberikan kemudahan bagi lembaga dalam mengatasi masalah dalam pengelolaan data narapidana dan memberikan laporan secara akurat dan cepat. Dalam penelitian ini digunakan metodologi: observasi, wawancara dan studi putaka untuk mencari sumber referensi yang berkaitan dengan penelitian ini. Metode perancangan menggunakan protoype untuk tampilan sistem agar sesuai dengan kebutuhan. Dengan adanya sistem ini diharapkan mampu membantu Lembaga Pemasyarakatan kelas IIA Pemuda Tangerang.
\end{abstract}

Kata kunci : Lembaga Pemasyarakatan, Pengelolaan data, kegiatan kerja

\section{ABSTRACT}

The system is a component that is interconnected to achieve a goal, the need for a computerized system that became the foundation of this information system he designed. The purpose of the system design data management coaching work activities of inmates in correctional institutions class IIA youth Tangerang is speeding up how the guards in the management of data on work activities and the activities performed by the inmates, increasing the performance of the warden in managing the data of prisoners and in the presentation of reports by utilizing a computerized system that will get the better information. Does the design of this system because the system is running before using the manual recording process because the work still using the writing on the paper, so it does not have a system that produces timely information for data management inmates who will carry out work activities. Therefore the computerized activity is expected to provide facilities for the institution in addressing problems in data management and reporting inmate accurately and quickly. In the study the authors used a methodology: observation, interviews and studies putaka to find the source of 
reference related to this research. Protoype design method used to display the system to fit the needs. With this system is expected to help Penitentiary Tangerang Youth class IIA.

Keywords : Penitentiary, data management, work activities.

\section{PENDAHULUAN}

Lembaga pemasyarakatan pemuda adalah lembaga pemasyarakatan kelas IIA Pemuda Tangerang yang menampung narapidana tindak kriminal dan narkoba sejak tanggal 16 Desember 1983. Lembaga pemasyarakatan kelas IIA Pemuda Tangerang terletak didaerah yang tidak begitu jauh dari pusat kota Tangerang dan pemukiman warga. Lembaga pemasyarakatan kelas IIA Pemuda Tangerang berkapasitas maksimal 1356 warga binaan sedangkan jumlah narapidana pada tahun 2015 adalah 1988 warga binaan yang terdiri dari 539 tahanan, 1449 narapidana dan kemungkinan dapat bertambah hingga tahun 2016 (sumber : KPLP, per September 2015) ${ }^{[17]}$.

Karena jumlah narapidana yang terus bertambah sampai akhirnya lapas pemuda melebihi kapasitas, jumlah dalam menampung para narapidana yang melebihi jumlah kapasitas maksimalnya yang berlebih hingga $46 \%$ (sumber : KPLP) ${ }^{[17]}$. Sehingga tidak sesuai dengan jumlah sipir yang menjaga ruangan sel, sehingga ada yang menyebabkan timbulnya banyak permasalahan didalam lapas, contohnya sering terjadi keributan antar narapidana, bisa menimbulkan tindak kriminalitas didalam penjara seperti peredaran narkoba dan tindak kejahatan pemerasan. Bahkan jumlah narapidana selalu meningkat pada 5 tahun terakhir ini dimana pada tahun 2010 jumlah narapidana nya adalah 1874 warga binaan dan pada tahun 2011 adalah 1976 warga binaan, tahun 2012 jumlah narapidana 2115 warga binaan, tahun 2013 berjumlah 2029 warga binaan tahun
2014 jumlah narapina adalah 1984 warga binaan dapat dilihat dari data berikut ini jumlah warga binaan yang begitu banyak tidak sesuai dengan jumlah sipir yang hanya berjumlah 175 (sumber : KPLP) ${ }^{[17]}$. Pada lembaga pemasyarakatan kelas IIA Pemuda Tangerang ini setiap sipir mempunyai pekerjaannya masingmasing yang behubungan dengan narapidana dimana pekerjaan itu dilakukannya dengan menggunakan teknologi komputer untuk memudahkan dalam melakukan pengolahan data yang dapat menghemat waktu yang dipakai dengan demikian pekerjaan akan lebih cepat selesai dan hasilnya pun akan baik.

Maka hasil yang didapatkan akan sangat memuaskan, berguna dan bermanfaat bagi lembaga pemasyarakatan ataupun instansi pemerintah terkait yang menggunakan laporan data narapidana tersebut. Dengan adanya teknologi komputer yang dapat membantu untuk meningkatkan kualitas dan juga profesionalisme yang dimiliki oleh sipirnya, sehingga memiliki pekerjaan yang bagus dan baik sehingga menjadikan lembaga ataupun instansi pemerintah yang memiliki kualitas yang tinggi.

Demikian juga dirasakan oleh beberapa lembaga-lembaga pemerintahan diantaranya dilembaga pemasyarakatan kelas IIA Pemuda Tangerang yang bergerak dibidang hukum dan hak asasi manusia yang menggunakan teknologi untuk menunjang suatu kegiatan yang dikerjakan oleh para sipir nya untuk dapat memudahkan dalam pengelolaan data narapidana yang berada dilembaga pemasyarakatan kelas IIA Pemuda Tangerang. 
Dengan adanya teknologi tersebut maka dibutuhkan suatu perancangan sistem untuk mengelola pendataan narapidana selama narapidana tersebut masih berada didalam tahanan dan sampai mendapatkan surat kebebasan dari lembaga pemasyarakatan kelas IIA Pemuda Tangerang, sehingga menjadi sebuah informasi yang terperinci dan akurat akan kebenaran laporan tersebut.

Didalam lapas terdapat suatu bagian-bagiannya salah satunya merupakan bagian giatja (kegiatan kerja) yang dilakukan oleh narapidana. Dimana narapidana akan melakukan kegiatan kerja tersebut apabila masa tahanan narapidananya tinggal $2 / 3$ atau $1 / 2$ dari putusan hukuman narapidana tersebut. Setelah itu maka akan diputuskan kegiatan kerja apa yang akan dilakukan oleh narapidananya, dengan demikian dukungan sistem komputerisasi sangatlah menunjang untuk kegiatan kerjanya.

\section{PERMASALAHAN}

Adapun permasalahan-permasalahan yang dihadapi oleh lembaga pemasyarakatan kelas IIA pemuda Tangerang dalam sistem pengelolaan data narapidana untuk bagian pembinaan kegiatan kerja narapidana antara lain adalah :

1. Bagaimana membuat suatu sistem yang dapat membantu para sipir dalam mendata narapidana yang akan melakukan pembinaan kagiatan kerja ?

2. Bagaimana mengimplementasikan sistem pengelolaan data narapidana menjadi terkomputerisasi ?

3. Bagaimana membuat suatu sistem yang dapat merekap hasil semua kegiatan narapidana yang telah dikerjakannya?

\section{LITERATUR REVIEW}

Dalam upaya mengembangkan dan menyempurnakan penelitian ini perlu dilakukan studi pustaka (literature review) sebagai salah satu penerapan metode penelitian yang akan dilakukan sebagai bahan perbandingan. Diantaranya yaitu:

1. Penelitian yang telah dilakukan oleh Riki Afrizal ,SH (2011) ${ }^{[1]}$ dari Universitas Andalas Berjudul "Efektivitas Pelaksanaan Asimilasi Pada Lembaga Pemasyarakatan Terbuka Dalam Mencapai Tujuan Sistem Pemasyarakatan". Penelitian ini bertujuan mengembalikan narapida- na kedalam lingkungan masyarakat sebagai warga yang baik. Salah satu upaya untuk mewujudkan tujuan tersebut adalah dengan pelaksanaan asimilasi. Adapun kendala-kendala yang ada dalam pelaksanaan pembinaan tidak memberikan pengaruh yang besar terhadap pelaksanaan kegiatan pembinaan tersebut. Diharapkan Agar kedepannya penempatan narapidana pada lapas sebagai tempat melaksanakan asimilasi bagi narapidana perlu tingkatkan lagi.

2. Penelitian yang telah dilakukan oleh Kristina Sitanggang (2014) ${ }^{[9]}$ dari Universitas Sumatera Utara. Berjudul "Pembinaan Terhadap Narapidana (Studi Di Lembaga Pemasyarakatan Kelas IIB Kota Langsa)". Penelitian ini dilakukan untuk mengatasi hambatan dalam proses pembinaan narapidana dilembaga pemasyarakatan Kelas IIB Kota Langsa. Adapun Hambatan yang dihadapi Lembaga Pemasyarakatan Kelas IIB Kota Langsa baik hambatan yang datang dari proses pembinaan didalam lembaga pemasyarakatan maupun hambatan dari proses pembinaan 
diluar lembaga pemasyarakatan adalah dilihat dari segi fasilitas.

3. Penelitian yang telah dilakukan oleh Ahmad Syaifuddin dan Dra. Nunuk Giari Murwandani, M.Pd (2015) ${ }^{[13]}$ dari Universitas Negeri Surabaya. Berjudul "Pembinaan Warga Binaan Di Lembaga Pemasyarakatan Lamongan Melalui Keterampilan Kerajinan". Penelitian ini dilakukan untuk mengetahui proses pembinaan keterampilan kerajinan dilembaga pemasyarakatan lamongan. Diharapkan lembaga pemasyarakatan kelas IIB lamongan sebagai lembaga yang bertanggung jawab terhadap pembinaan warga binaan agar mengembangkan lagi dalam hal jenis keterampilan.

4. Penelitian yang telah dilakukan oleh Pramudhya Tyaswuri (2010) ${ }^{[14]}$ dari Universitas Negeri Yogyakarta. Berjudul "Implementasi Life Skills Pelatihan Keterampilan Pertukangan Kayu Bagi Warga Binaan DiLembaga Pemasyarakatan Klas IIA Yogyakarta". Subyek penelitian ini adalah ketua koordinator bidang kerja, instruktur atau pelatih keterampilan pertukangan kayu dan warga binaan. Pengumpulan data dilakukan dengan menggunakan metode pengamatan, wawancara dan dokumentasi. Hasil penelitian menunjukan pelaksanaan pelatihan keterampilan pertukangan kayu bagi warga binaan dan faktor yang menghambat yaitu warga binaan mempunyai sifat yang mudah tersinggung sehingga pada proses pembelajaran sering terjadi perselisihan antar warga binaan.

5. Penelitian yang telah dilakukan oleh Rio Pratikno (Diakses tanggal 7 Oktober 2015) ${ }^{[8]}$ Universitas Maritim Raja Ali Haji. Berjudul "Evaluasi Program Pembinaan Keterampilan Kerja Bagi Warga Binaan Pemasyarakatan Di Lembaga
Pemasyarakatan Kelas IIA

Tanjungpinang". Adapun tujuan penelitian ini adalah untuk mengevaluasi program pembinaan keterampilan kerja bagi warga binaan pemasyarakatan di Lembaga Pemasyarakatan Kelas IIA Tanjungpinang faktor penghambat dalam indikator tingkat permasalahan dalam pembinaan keterampilan kerja yaitu indikator ketersedian dana dan ketersedian tenaga ahli dalam mengajarkan keterampilan kerja bagi narapidana.

6. Penelitian yang telah dilakukan oleh Anang Cahyono Sugeng (2014) ${ }^{[10]}$ Universitas Tulungagung Bonorowo berjudul "Pemberdaya an Dan Pengembangan Keterampilan Warga Binaan Di Lembaga Pemasyarakatan Kelas IIB Tulugagung”. Beberapa kegiatan yang dikembangkan oleh para warga binaan dengan pihak LP merupakan upaya nyata yang dilakukan tidak hanya untuk mengisi kegiatan di lp akan tetapi kemampuan para warga binaan tersebut dapat terus berkembang ketika mereka sudah selesai menjalani masa binaan. Tujuan besar dari upaya ini adalah menciptakan sumberdaya manusia baru yang mampu melalui jalur kewirausahaan. Pada tahapan pelaksanaannya LP Kelas IIB Tulungagung memiliki beberapa kendala diantaranya keterbatasan sumber daya manusia dan modal untuk pengembangan usaha.

Adapun kesimpulan dari ke 6 (enam) literature review diatas adalah Dengan adanya proses pembinaan kegiatan kerja narapidana dilembaga pemasyarakatan bertujuan untuk membantu mengembangkan keahlian dan keterampilan yang ada pada narapidana dan membantu narapidana untuk mengembalikan narapi- 
dana kedalam lingkungan masyarakat sebagai warga yang baik.

\section{LANDASAN TEORI}

\section{Definisi Sistem}

Menurut Ludwig Von Bertalanfly dalam Yakub (2014:2) $)^{[16],}$ "Sistem merupakan seperangkat unsur-unsur yang terkait dalam suatu antar relasi diantara unsur-unsur tersebut dan dengan lingkungannya".

\section{Definisi Informasi}

Menurut George H.B \& William S.H. $(2014: 18)^{[4]}$, "Informasi adalah data diolah sehingga dapat dijadikan dasar untuk mengambil keputusan".

\section{Definisi Data \& Pengelolaan Data}

Menurut Hartono (2013:9) ${ }^{[5]}$, "Data adalah hasil pengukuran dan pencatatan data terhadap fakta tentang sesuatu, keadaan, tindakan atau kejadian".

Menurut Yakub (2012:17) $)^{[16]}$, "Sistem informasi dalam organisasi biasanya terdiri atas berbagai metode pengelolaan data". Metode pengelolaan data terdiri dari: 1) Metode manual, merupakan pengelolaan data yang semua operasi datanya dilakukan dengan tangan dan bantuan alat-alat. 2) Metode electromechanical, yang merupakan pengelolaan data dengan menggabungkan semua orang dan mesin. 3) Metode punched card equipment, merupakan pengelolaan data yang menggunakan semua alat yang disebut sistem warkat unit (unit record system). 4) Metode electronic computer, merupakan pengelolaan data dengan menggunakan komputerisasi.

\section{Definisi Website}

Menurut Yosef Murya $(2012: 3)^{[7]}$ "Website atau World Wide Web adalah Suatu layanan sajian informasi yang menggunakan konsep hyperlink (tautan) dengan menggunakan media untuk memudahkan surfer (sebutan para pemakai komputer yang melakukan browsing atau penelusuran informasi melalui internet)" didalam pencarian informasi.

\section{Definisi Narapidana}

Menurut Heru Susetyo dikutip dari laporan Tim Pengkajian Hukum $(2012: 3)^{[12]}$, "Narapidana adalah terpidana yang menjalani pidana hilang kemerdekaan di Lembaga Pemasyarakatan (Lapas) yaitu seseorang yang dipidana berdasarkan putusan pengadilan yang telah memperoleh kekuatan hukum".

"Pengertian narapidana berasal dari dua suku kata yaitu Nara artinya orang dan Pidana artinya hukuman dan kejahatan (pembunuhan, perampokan, penganiayaan, narkoba, korupsi dan sebagainya). Jadi pengertian narapidana menurut Kamus Besar Bahasa Indonesia diartikan sebagai orang hukuman (orang yang menjalani hukuman) karena melakukan tindak pidana" Kamus Besar Bahasa Indonesia (2010:612) ${ }^{[16]}$.

Dalam Pasal 1 butir 2 Bab I Ketentuan Umum Undang-Undang Nomor 12 tahun 1995 tentang pemasyarakatan yang dimaksud dengan sistem pemasyarakatan adalah: Suatu tatanan mengenai arah dan batas serta cara pembinaan warga binaan pemasyarakatan berdasarkan pancasila yang dilaksanakan secara terpadu antara pembina yang dibina dan masyarakat untuk meningkatkan kualitas warga binaan pemasyarakatan agar menyadari kesalahan, memperbaiki diri dan tidak mengulangi tindak pidana sehingga dapat diterima kembali oleh lingkungan masyarakat, dapat aktif berperan dalam pembangunan dan dapat hidup secara wajar sebagai warga yang baik dan bertanggung jawab. 


\section{Definisi Pembinaan Narapidana}

Menurut Pamudji dalam Jurnal Ahmad Saifuddin dan Nunuk Giari Murwandani (2015:128) $)^{[13]}$, "Pembinaan berasal dari kata bina yang berarti sama dengan bangun, jadi pembinaan dapat diartikan sebagai kegunaan yaitu: merubah sesuatu sehingga menjadi baru yang memiliki nilai-nilai yang tinggi. Dengan demikian, pembinaan juga mengandung makna sebagai pembaharuan, yaitu: melakukan usahausaha untuk membuat sesuatu menjadi lebih sesuai atau cocok dengan kebutuhan dan menjadi lebih baik dan lebih bermanfaat".

Selanjutnya, menurut Hidayat dalam Dinar dan Farid (2014:2) $)^{[3]}$, "Pembinaan adalah suatu usaha yang dilakukan dengan sadar, berencana, teratur dan terarah untuk meningkatkan sikap dan keterampilan anak didik dengan tindakan-tindakan, pengarahan, pembimbingan, pengembangan, stimulasi dan pengawasan untuk mencapai suatu tujuan".

Menurut ketentuan Keputusan Menteri Kehakiman Nomor: M.02PK.04.10 Tahun 1990 ${ }^{[11]}$ tentang Pola Pembinaan Narapidana atau Tahanan, menyatakan pengertian pembinaan adalah Pembinaan meliputi tahanan, pelayanan tahanan, pembinaan narapidana dan bimbingan klien.

Pelayanan tahanan adalah segala kegiatan yang dilaksanakan dari mulai penerimaan sampai dalam tahap pengeluaran tahanan.

Pembinaan narapidana adalah semua usaha yang ditujukan untuk memperbiki dan meningkatkan akhlak (budi pekerti) para narapidana yang berada didalam Lembaga Pemasyarakatan.

Bimbingan klien ialah semua usaha yang ditujukan untuk memperbaiki dan meningkatkan akhlak (budi pekerti) para klien pemasyarakatan diluar tembok.

"Ditinjau dari segi bahasa, Pembinaan diartikan sebagai Proses, cara, perbuatan membina, kegiatan yang dilakukan secara efisien dan efektif untuk memperoleh hasil yang lebih baik" Kamus Besar Bahasa Indonesia (2010: $655)^{[6]}$.

Pembinaan narapidana merupakan salah satu upaya yang bersifat Ultimum Remidium (upaya terakhir) yang lebih tertuju kepada alat, agar narapidana sadar akan perbuatannya sehingga pada saat kembali kedalam masyarakat ia akan menjadi baik, baik dari segi keagaman, sosial budaya maupun moral sehingga akan tercipta keserasian dan keseimbangan ditengah-tengah masyarakat. Pemasyarakatan membentuk sebuah prinsip pembinaan dengan sebuah pendekatan yang lebih manusiawi hal tersebut terdapat dalam usaha-usaha pembinaan yang dilakukan terhadap pembinaan dengan sistem pemasyarakatan seperti yang diatur dalam Undang-undang Nomor 12 tahun 1995 tentang pemasyarakatan.

Menurut Artikel Riki Afrizal $(2011: 5)^{[1]}$, "Setelah adanya UndangUndang Nomor 12 Tahun 1995 Tentang Pemasyarakatan, maka untuk pelaksanaan pembinaan narapidana selanjutnya mengacu pada undang-undang tersebut. Pembinaan narapidana dilapas dilaksanakan dengan beberapa tahapan pembinaaan yaitu tahap awal, tahap lanjutan dan tahap akhir". Adapun pelaksanaan tahapan pembinaan tersebut adalah sebagai berikut: 1) Pembinaan tahap awal bagi narapidana dilaksanakan sejak narapidana tersebut berstatus sebagai narapidana hingga latau 3 (satu per tiga) masa pidananya. 2) Pembinaan tahap lanjutan terbagi kedalam dua bentuk, yaitu : Tahap lanjutan pertama, dimulai sejak berakhirnya pembinaan tahap awal sampai dengan $1 / 2$ (satu per dua) masa 
pidananya. Tahap lanjutan kedua, dimulai sejak berakhirnya pembinaan tahap lanjutan pertama sampai dengan $2 / 3$ (dua per tiga) masa pidananya.

Pembinaan tahap akhir, di laksanakan sejak berakhirnya pembinaan tahap lanjutan sampai dengan berakhirnya masa pidana narapidana yang bersangkutan.

\section{Definisi Lembaga Pemasyara-}

\section{katan}

Menurut Soedjono Dirdjosisworo

dalam Skripsi Sartika Budi A $(2013: 16)^{[2]}$, "Lembaga Pemasyarakatan sebagai tempat dimana terpidana mengalami proses pembinaan dalam menjalankan pidananya berdasarkan putusan Hakim".

Menurut Undang-Undang Nomor 12 Tahun 1995" ${ }^{[15]}$, "Pemasyarakatan Lembaga Pemasyarakatan (disingkat Lapas) adalah tempat untuk melakukan pembinaan terhadap narapidana dan anak didik pemasyarakatan diIndonesia. Sebelum dikenal istilah lapas diIndonesia, tempat tersebut disebut dengan istilah penjara".

Penghuni Lembaga Pemasyarakatan bisa narapidana (napi) atau Warga Binaan Pemasyarakatan (WBP) bisa juga yang statusnya masih tahanan, maksudnya orang tersebut masih berada dalam proses peradilan dan belum ditentukan bersalah atau tidak oleh hakim.

\section{PEMBAHASAN}

Lembaga Pemasyarakatan (Lapas) kelas IIA pemuda Tangerang dibentuk berdasarkan surat keputusan menteri kehakiman republik Indonesia, tanggal 16 Desember 1983 nomor: M.03.UM.01.06 tahun 1983 tentang penetapan lembaga pemasyarakatan tertentu sebagai rumah tahanan negara. Dalam lampiran II surat keputusan tersebut lapas kelas IIA pemuda Tangerang disamping sebagai lapas, juga sebagian ruangnya ditetapkan atau difungsikan sebagai rumah tahanan negara (rutan).

Seperti diketahui bahwa lapas adalah tempat untuk melakukan pembinaan terhadap pelanggaran hukum yang sudah diputus oleh hakim dan sudah mempunyai ketetapan hukum yang tetap. Sedangkan rumah tahanan negara merupakan tempat yang diperuntukkan bagi pelanggar hukum yang masih dalam proses peradilan baik dalam tahapan penyidikan, penuntutan ataupun mereka yang masih dalam proses pemeriksaan dipengadilan.

Dalam surat edaran Direktur Jenderal pemasyarakatan tanggal 26 Juni 1985 nomor: E.PS.01.10-116 tentang penempatan narapidana, anak negara dan anak sipil dinyatakan bahwa narapidana dewasa adalah narapidana yang berumur lebih dari 21 tahun. Narapidana pemuda adalah mereka yang berumur antara 18 tahun sampai 21 tahun. Sedangkan narapidana anak adalah mereka yang berumur dibawah 18 tahun. Sedangkan berdasarkan surat kepala kantor wilayah departemen wilayah VII DKI Jaya 18 februari 1984 nomor: W7.UM.01.06. 923.84, lembaga pemasyarakatan kelas IIA pemuda Tangerang juga dijadikan tempat penampungan narapidana yang berusia maksimal 27 tahun.

Namun penepatan tersebut pada saat ini tidak dapat dilaksanakan secara utuh, karena pada akhir-akhir ini ada kecenderungan makin meningkatnya jumlah penghuni diwilayah DKI Jakarta, sehingga lembaga pemasyarakatan kelas IIA pemuda Tangerang oleh pimpinan wilayah difungsikan sebagai lapas penyangga dari adanya kecenderungan kapasitas berlebih dilapas cipinang, rutan salemba dan lapas kelas IA Tangerang. Akibatnya fungsi sebagai lembaga pemasyarakatan yang khusus menampung dan membina narapidana pemuda sudah tidak murni lagi. Hal itu diperkuat lagi 
dengan ditetapkan nya lembaga pemasyarakatan kelas IIA pemuda Tangerang sebagai rumah tahanan yang notabene tidak mengenal pengkelasifikasian ditinjau dari aspek umur.

Tata laksana sistem yang berjalan pada lembaga pemasyarakatan kelas IIA pemuda Tangerang ini berdasar kepada urutan prosedur yang telah ditetapkan. Urutan prosedur ini berisikan urutan proses menunggu nya surat keputusan dari bagian registrasi, registrasi merupakan bagian yang mempunyai tugas untuk membuat surat keputusan asimilasi narapidana. Pada bagian kegiatan kerja memproses surat keputusan, memanggil nama-nama narapidana yang ada disurat keputusan, narapidana melakukan persidangan didalam ruangan kegiatan kerja, bagian kegiatan kerja membuat jadwal kegiatan kerja narapidana dengan urutan sebagai berikut: 1) Surat keputusan dari registrasi; Pada bagian kegiatan kerja akan mendapatkan surat keputusan dari bagian registrasi yang berisikan namanama narapidana yang telah menjalankan $2 / 3$ atau $1 / 2$ tahun masa hukumannya. 2) Bagian kegiatan kerja memproses surat keputusan registrasi; Setelah mendapatkan surat keputusan bagian kegiatan kerja akan memproses data nya dengan cara menulis siapa saja narapidana yang terdata pada surat keputusan tersebut. 3) Memanggil nama-nama narapidana yang terdapat disurat keputusan. Lalu setelah menuliskan semua-nya pada bagian kerja akan memanggil satu persatu narapidana yang telah bisa melakukan kegiatan kerja. Setelah di panggil narapidana akan diberi tahukan jadwal persidangan yang akan dijalankannya. 4) Narapidana akan melaksanakan persidangan didalam ruangan kegiatan kerja. Narapidana akan diproses terlebih dahulu apakah narapidana tersebut layak atau tidak layak melakukan kegiatan kerja ini, kemudian datanya akan diberikan lagi kepada bagian registrasi untuk dibuatkan surat keputusan lagi dan apabila layak maka narapidana akan menunggu lagi paling cepat 1 hari dan paling lama 2 hari untuk mengetahui jadwal kegiatan kerjanya. 5) Bagian kegiatan kerja membuat jadwal kegiatan kerja narapidana.

Setelah narapidana melakukan persidangan bagian kegiatan kerja harus menunggu lagi surat keputusan mengenai kelayakan narapidana tersebut. Setelah mendapatkan surat keputusan terbaru lalu bagian kegiatan kerja akan membuat jadwal kegiatan kerja nya dan pelaksanaan kerja narapidana apakah narapidana tersebut ditempatkan untuk bekerja diluar lapas atau didalam lapas.

Prosedur yang lainnya yakni mengenai Prosedur Sistem Pembinaan Kegiatan Kerja pada Lembaga Pemasyarakatan Kelas IIA Pemuda Tangerang sebagai berikut: 1) Bagian Registrasi; Bagian registrasi memberikan surat keputusan narapidana yang masa tahanannya tinggal $2 / 3$ atau $1 / 2$ kepada bagian giatja (kegiatan kerja). 2) Bagian Giatja (kegiatan kerja); Pada bagian kegiatan kerja memproses surat keputusan yang telah diberikan oleh bagian registrasi lalu memanggil namanama narapidana yang terdapat pada surat keputusan tersebut. 3) Narapidana menjalankan persidangan; Setelah dipanggil oleh bagian kegiatan kerja lalu narapidana akan melaksanakan persidangan. Pada persidangan ini untuk menentukan apakah narapidana ini layak untuk bisa melaksanakan kegiatan atau tidak dan menentukan lokasi dimana narapidana akan melaksanakan kegiatan kerja. 4) Bagian Registrasi; Setelah narapidana melaksanakan persidangan lalu pada bagian registrasi mengupdate surat keputusan dengan menambahkan lokasi kegiatan kerja yang akan dilakukan oleh narapidana yang sudah diputuskan saat persidangan. Lalu surat keputusan akan diberikan kembali kepada bagian giatja (kegiatan kerja). 5) Bagian Kegiatan kerj; Disaat surat keputusan 
yang terbaru telah diberikan maka bagian kegiatan kerja akan membuatkan jadwal sesuai surat keputusan yang terbaru dan menentukan kegiatan kerja apa yang akan dilakukan oleh narapidana dan jadwal tersebut akan diberitahukan oleh narapidana. 6) Narapidana diberikan Jadwal Kegiatan Kerja; Setelah mengetahui jadwal yang sudah dibuat oleh bagian kegiatan kerja lalu narapidana akan melaksanakan kegiatan kerja sesuai dengan jadwalnya sampai masa tahanan nya berakhir (bebas).

Dibawah ini merupakan gambaran sistem pembinaan kegiatan kerja pada Lembaga Pemasyarakatan Kelas IIA Pemuda Tangerang yang berjalan digambarkan melalui bentuk gambar ilustrasi proses kegiatan kerja :

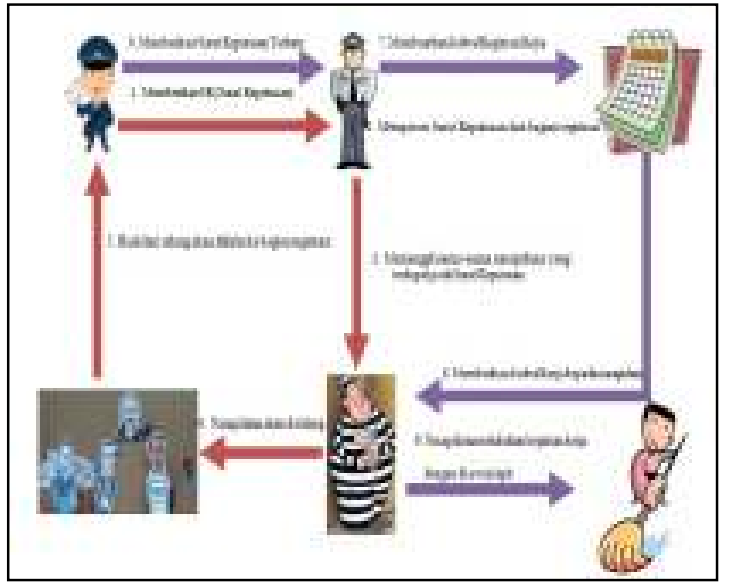

Gambar 1. Sistem Pembinaan Kegiatan Kerja

Keterangan gambar 1 tentang alur sistem pembinaan kegiatan kerja, yaitu: 1) Memberikan SK (Surat Keputusan), 2) Memproses Surat Keputusan dari bagian registrasi, 3) Memanggil namanama narapidana yang terdapat pada Surat Keputusan, 4) Narapidana akan disidang, 5) Hasil dari sidang akan dikirim kebagian registrasi, Memberikan Surat Keputusan terbaru, 7) Membuatkan jadwal kegiatan kerja, 8) Memberikan jadwal kerja kepada narapidana, 9) Narapidana melakukan kegiatan kerja dengan diawasi sipir.

\section{MODEL SISTEM}

Model sistem yang terdapat pada pembinaan kegiatan kerja pada lembaga pemasyarakatan kelas IIA pemuda Tangerang:

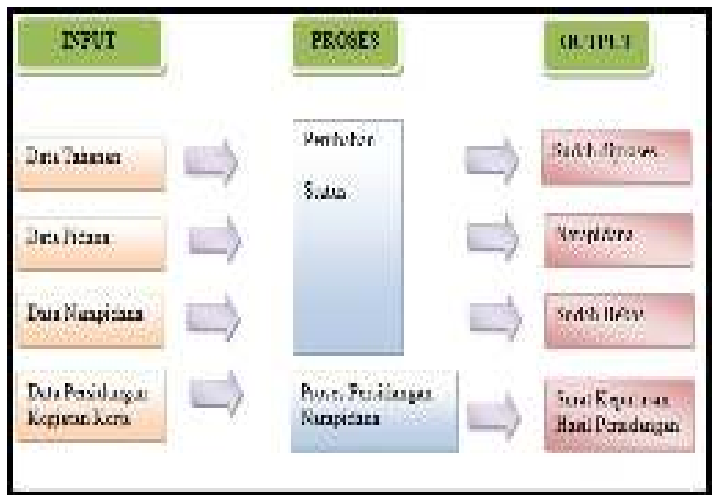

\section{Gambar 2. Model Sistem Lp Kelas IIA Pemuda Tangerang}

\section{Keterangan :}

1) Inputan data tahanan yang berupa dokumen akan diproses, dimana proses ini digunakan untuk merubah status tahanan menjadipidana, 2) Data pidana akan dilakukan proses lanjutan yaitu perubahan status dari pidana menjadi narapidana, 3) Masing-masing narapidana akan mengalami proses persidangan sesuai dengan catatan perilakunya, jika narapidana tersebut memiliki perilaku baik maka narapidana akan menjalankan kegiatan kerja diluar lapas, jika perilakunya cukup baik maka narapidana akan menjalankan kegiatan kerja didalam lapas.

Kegunaan dari model sistem tersebut adalah untuk menggambarkan model alur sistem yang terdapat dalam lembaga pemasyarakatan kelas IIA pemuda Tangerang, selain itu model sistem juga digunakan sebagai skema alur dari perancangan sistem yang diusulkan oleh peneliti. 
Berikut adalah prosedur sistem usulan pembinaan kegiatan kerja pada lembaga pemasyarakatan kelas IIA pemuda Tangerang melalui bentuk gambar ilustrasi proses sistem usulan pembinaan kegiatan kerja :

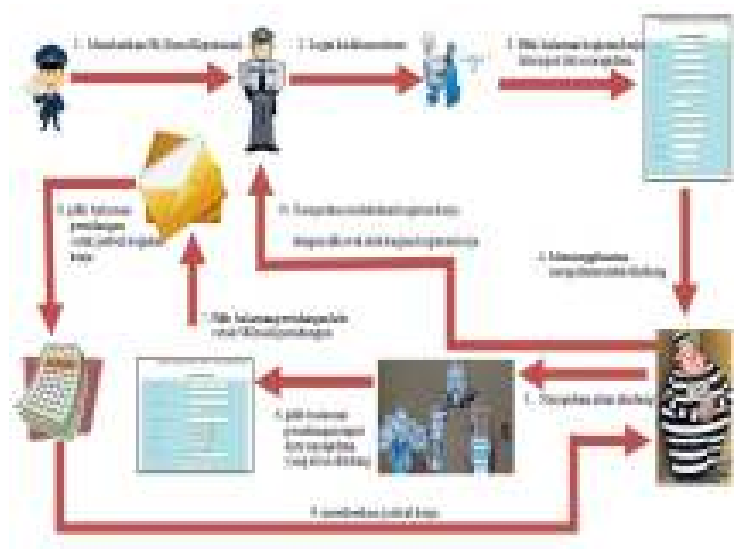

\section{Gambar 3. Sistem Usulan Pembinaan Kegiatan Kerja}

Prosedur sistem usulan pembinaan kegiatan kerja pada lembaga pemasyarakatan kelas IIA pemuda Tangerang yang diusulkan sebagai berikut:

1) Bagian registrasi memberikan $\mathrm{SK}$ (surat keputusan) kepada bagian kegiatan kerja, 2) Lalu bagian kegiatan kerja login kedalam sistem, 3) Setelah login bagian kegiatan kerja memilih halaman kegiatan kerja untuk menginputkan data narapidana, 4) Bagian kegiatan kerja memanggil nama narapidana untuk disidangkan narapidananya, 5) Narapidana akan disidangkan untuk menentukan kelayakannya narapidana dapat melaksanakan kegiatan kerja dan pekerjaan yang akan dilakukan oleh narapidana, 6) Pada saat persidangan bagian kegiatan memilih halaman persidangan untuk menginputkan semua data narapidana dalam menentukan kelayakan narapidana untuk melaksanakan kegiatan kerja dan pekerjaan yang akan dilakukan oleh narapidana, 7) Setelah melakukan persidangan bagian kegiatan kerja dapat langsung mecetak surat keputusan terbaru yaitu surat keputusan hasil persidangan, 8) Dan jadwal kegiatan kerja pun dapat langsung dicetak dengan pilih halaman persidangan, 9) Setelah jadwal dicetak maka jadwal dapat diberikan oleh narapidana, 10) Narapidana dapat melaksanakan kegiatan kerja dengan dikawal oleh bagian kegiatan kerja.

\section{IMPLEMENTASI}

Tampilan login merupakan tampilan utama dari sistem, setiap user yang ingin masuk ke dalam sistem maka harus melakukan login terlebih dahulu dengan memasukan username dan password yang benar.

Berikut dibawah ini merupakan tampilan login website Pengelolaan Data Pembinaan Kegiatan Kerja Narapidana:

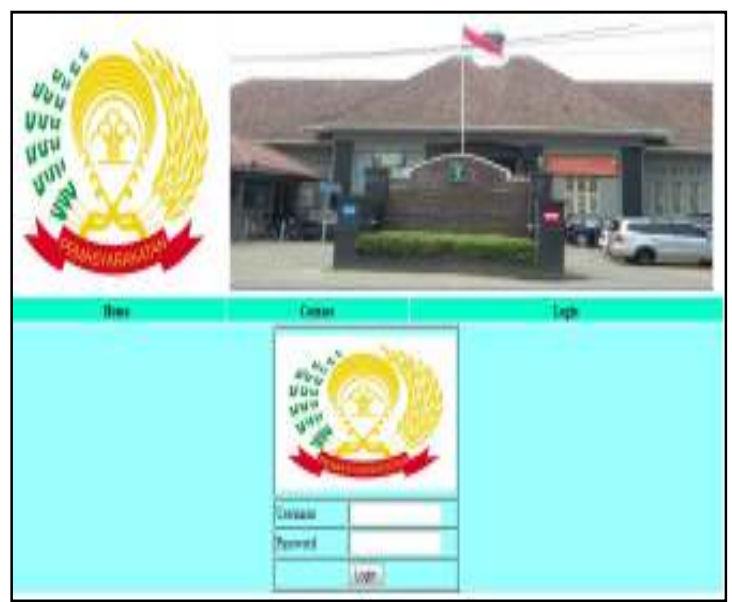

Gambar 4. Tampilan Halaman Login

Tampilan Home yang didalamnya terdapat halaman data penghuni, kegiatan kerja, rekap hasil kegiatan kerja dan Sign Out. 
Admin tidak sepenuhnya memiliki hak akses dalam sistem ini dikarenakan untuk halaman data penghuni hanya dapat diakses pada bagian registrasi.

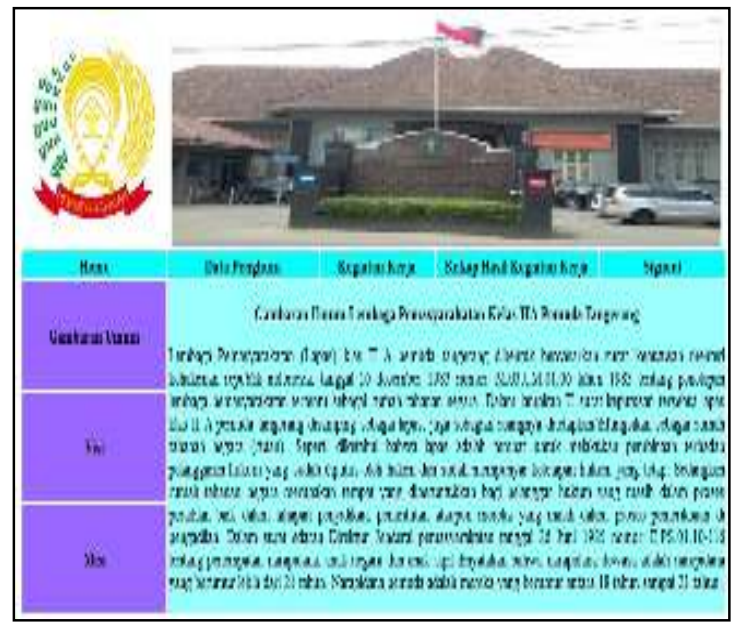

Gambar 5. Tampilan Halaman Home

Pada tampilan halaman kegiatan kerja ini terdapat tabel tampil narapidana dimana nanti nya pada halaman ini admin dapat memasukan No. SK Kegiatan Kerja narapidana yang akan melaksanakan kegiatan kerja.

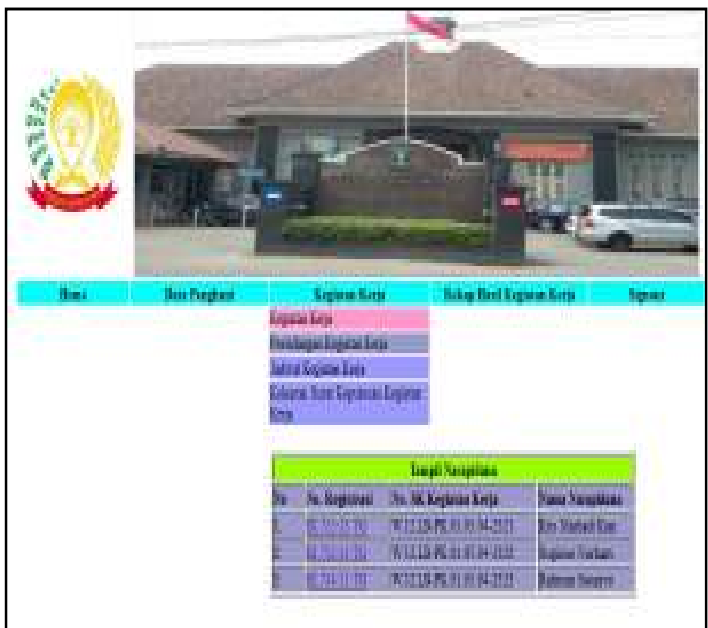

Gambar 6. Tampilan Halaman Kegiatan Kerja

Halaman persidangan kegiatan kerja ini akan digunakan saat narapidana akan disidangkan mengenai kelayakannya untuk melakukan kegiatan kerja, contoh : apabila narapidana selama masa hukuman memiliki perilaku baik maka narapidana tersebut akan melaksanakan kegiatan kerja diluar lapas, apabila narapidana tersebut memiliki perilaku yang cukup baik maka narapidana akan melaksanakan kegiatan kerja didalam lapas dan apabila narapidana memiliki perilaku yang tidak baik maka narapidana tersebut tidak dapat melakukan kerja baik didalam maupun diluar lapas dan setelah itu akan langsung diberikan pekerjaannya yang akan dilakukan oleh narapidana tersebut.

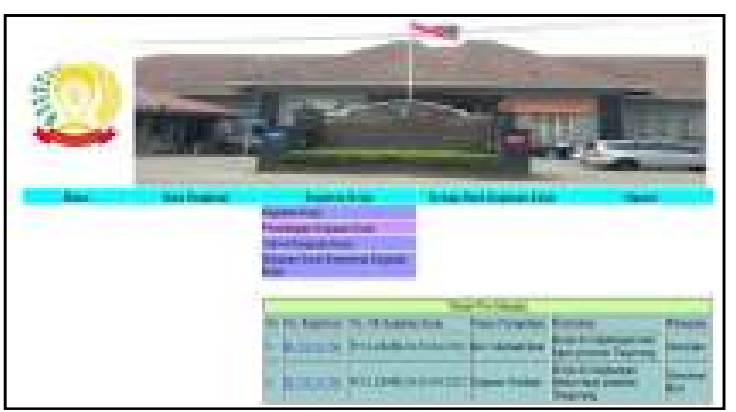

Gambar 7. Tampilan Halaman Persidangan Kegiatan Kerja

Halaman jadwal kegiatan kerja ini dapat langsung diprint apabila semua data-data sudah lengkap (data ini didapatkan semua pada saat persidangan). Setelah jadwal diprint maka narapidana bisa melaksanakan kegiatan kerja nya secara cepat tanpa harus menunggu lama.

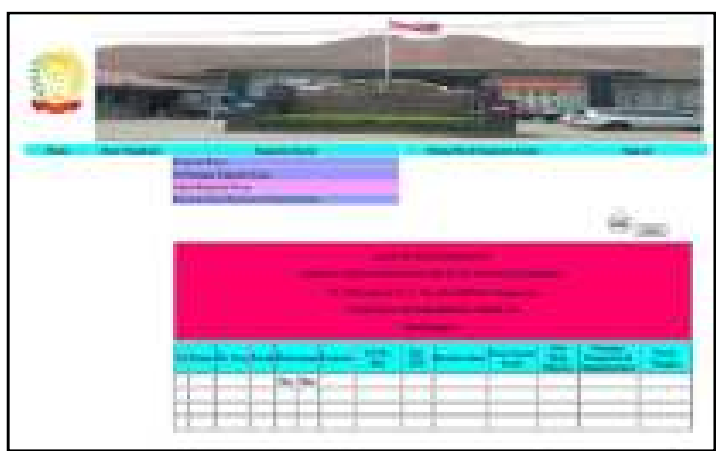

Gambar 8. Tampilan Halaman Jadwal Kegiatan Kerja 
Halaman surat keputusan persidangan ini pun dapat secara cepat di print tanpa harus menunggu dari bagian registrasi lagi.

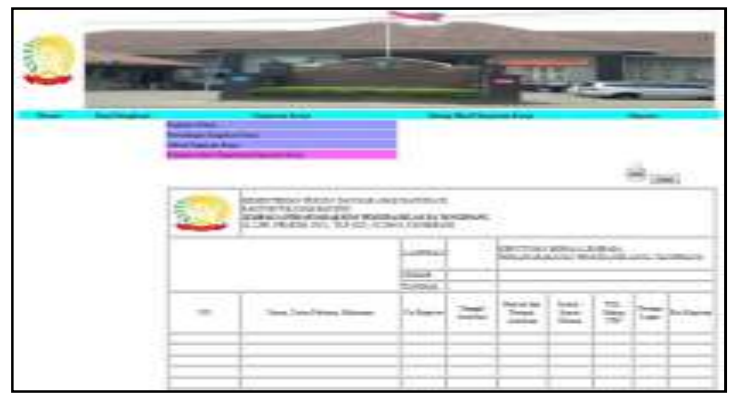

Gambar 9. Tampilan Halaman Keluaran Surat Keputusan Persidangan

Pada halaman nama-nama narapidana yang melakukan kegiatan kerja ini berisikan semua data narapidana yang sedang melaksanakan kegiatan kerja secara lengkap karena didalamnya terdapat pekerjaan dan petugas yang menjaga atau mengawasi narapidana.

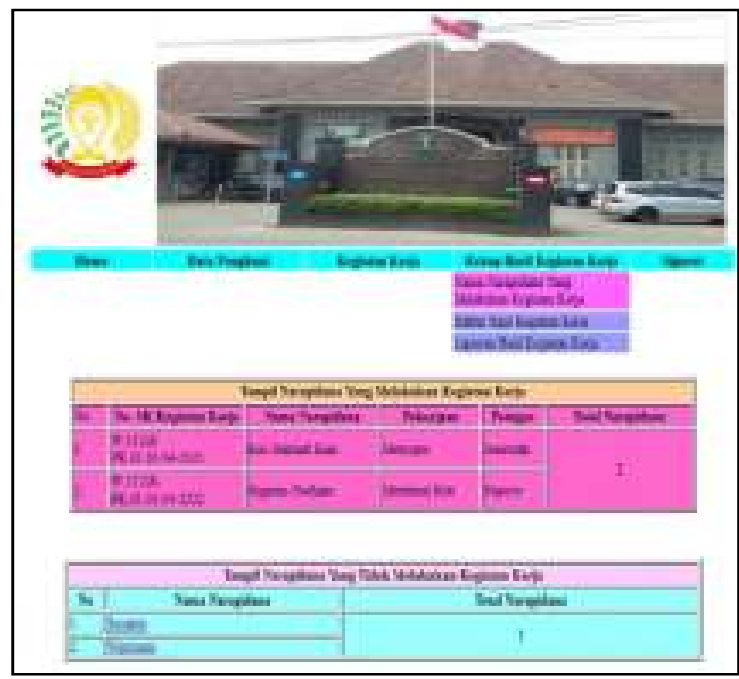

Gambar 10. Tampilan Halaman NamaNama Narapidana yang Melakukan Kegiatan Kerja

Pada halaman ini terdaftar daftardaftar narapidana yang bekerja dibagian kegiatan kerja yang bertugas untuk mengawasi narapidana yang melaksanakan kegiatan kerja

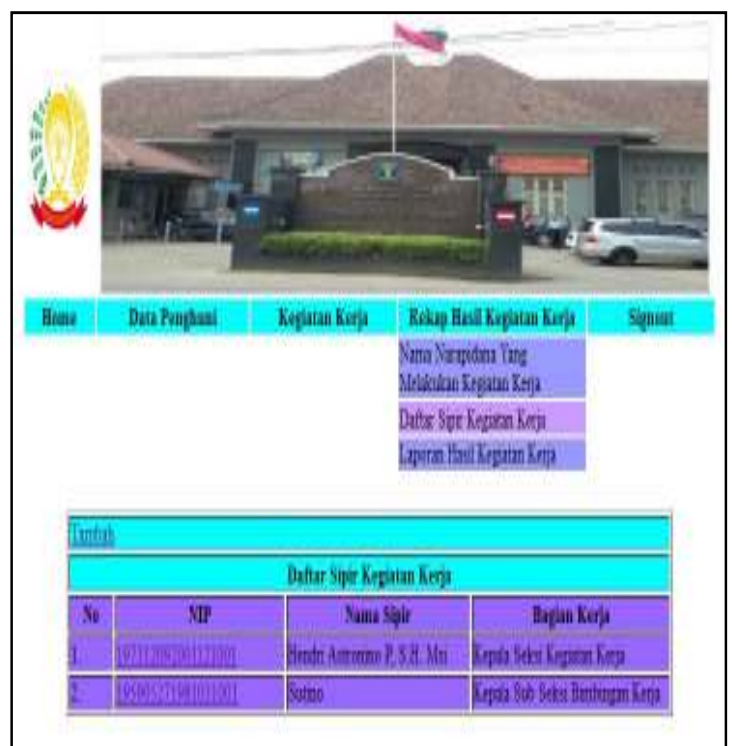

Gambar 11. Tampilan Halaman Daftar Sipir Kegiatan Kerja

Pada halaman laporan hasil kegiatan kerja ini berisikan bagian semua kerja dan petugasnya serta akan terperinci secara otomatis jumlah subtotalnya.

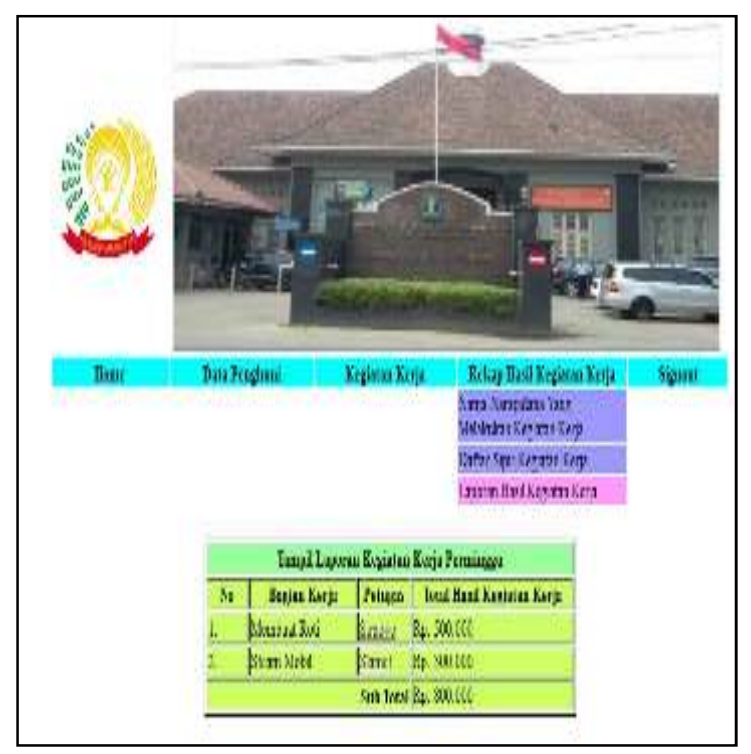

Gambar 12. Tampilan Halaman Laporan Hasil Kegiatan Kerja 


\section{KESIMPULAN}

Berdasarkan hasil penelitian yang telah dilakukan, maka dapat ditarik kesimpulan sebagai berikut :

Untuk membuat suatu sistem yang dapat membantu para sipir dalam mendata narapidana yang akan melakukan pembinaan kegiatan kerja adalah dengan menggunakan sistem informasi yang dibuat ini agar dapat lebih memudahkan didalam mendata narapidana yang akan melaksanakan asimilasi (pembinaan kegiatan kerja) dengan lebih cepat, sehingga dalam penyajian laporan data narapidana yang sedang melaksanakan kegiatan kerja akan menghasilkan laporan yang lebih baik.

Untuk dapat mengimplementasikan sistem pengelolaan data narapidana menjadi terkomputerisasi diperlukan suatu kegiatan yang berupa masa pengenalan dan percobaan selama melakukan implementasi pada sipir dibagian kegiatan kerja sehingga sipir akan menjalankan sistem dengan baik.

Untuk membuat suatu sistem yang dapat merekap hasil semua kegiatan narapidana yang telah dikerjakannya adalah dengan sistem informasi berbasis website, dengan sistem ini sipir dapat merekap semua hasil kegiatan kerja yang narapidana lakukan baik didalam lapas maupun diluar lapas sesuai dengan bagian pekerjaan yang dilakukan oleh narapidana secara lebih lengkap.

\section{DAFTAR PUSTAKA}

[1] Afrizal, Riki.2011.’Efektivitas Pelaksanaan Asimilasi Pada Lembaga Pemasyarakatan Terbuka Dalam Mencapai Tujuan Sistem Pemasyarakatan".

http://pasca.unand.ac.id/id/wpcontent/uploads/2011/09/ARTIKE L-RIKI-AFRIZALSH-_PDF .pdf .
[2] Budi A, Sartika.2013." Evaluasi Model Pembinaan Narapidana Di Lembaga Pemasyarakatan Kelas II A Wanita Semarang".Universitas Negeri Semarang.

[3] Dinar, M dan Farid, M. 2014. "Pembinaan Anak Penyandang Masalah Kesejahteraan Sosial diUnit Pelaksana Teknis Dinas (UPTD) Kampung Anak Negeri Kota Surabaya". Surabaya: Universitas Negeri Surabaya.

[4] H.B, George, William S.H.2014."Sistem Informasi Manajemen". Yogyakarta:Graha Ilmu.

[5] Hartono, Bambang. 2013. "Sistem Informasi Manajemen Berbasis Komputer”. Jakarta: Rineka Cipta.

[6] Kamus Besar Bahasa Indonesia.2010.'Kamus Bahasa Indonesia".Jakarta:Balai Pustaka.

[7] Murya,Yosef. 2012."PHP Menyelesaikan Website 30 Juta". Yogyakarta: Jasakom.

[8] Pratikno, Rio.’Evaluasi Program Pembinaan Keterampilan Kerja Bagi Warga Binaan Pemasyarakatan Di Lembaga Pemasyarakatan Kelas II A Tanjungpinang".Universitas Maritim Raja Ali Haji.Diakses tanggal 7 Oktober 2015.

[9] Sitanggang, Kristina. 2014." Pembinaan Terhadap Narapidana (Studi Di Lembaga Pemasyarakatan Kelas II B Kota Langsa)". Jurnal Fakultas Hukum Universitas Sumatera Utara.

[10] Sugeng Cahyono, Anang.2014. "Pem- berdayaan Dan Pengembangan Keterampilan 
Warga Binaan Di Lembaga

Pemasyarakatan Kelas IIB

Tulugagung". Jurnal Universitas

Tulungagung Bonorowo Vol.

2.No.1.

[11] Surat Keputusan Menteri

Kehakiman Nomor : M.02PK.04.10.

[12] Susetyo, Heru.2012.'Laporan Tim Pengkajian Hukum Tentang Sistem Pembinaan Narapidana Berdasarkan Prinsip Restorative Justice".Jakarta.

[13] Syaifuddin, Ahmad \& Nunuk Giari Murwandani.2015.'Pembinaan

Warga Binaan Di Lembaga Pemasyarakatan Lamongan Melalui Keterampilan Kerajinan". Jurnal Pendidikan Seni Rupa. Volume 03 Nomor 02.

[14]Tyaswuri,Pramudhya.2010.'Impleme ntasi Life Skills Pelatihan Keterampilan Pertukangan Kayu Bagi Warga Binaan Di Lembaga Pemasyarakatan Kelas IIA Yogyakarta". Skripsi Universitas Negeri Yogyakarta.

[15] UU No. 12 Tahun 1995.Di akses Tanggal 1 September 2015.

[16] Yakub.2012."Penghantar Sistem Informasi”.Yogyakarta:Graha Ilmu. 